Review Paper

\title{
ON THE ATTACK OF THE HUNGARIAN KING BELA III ON SERBIA IN LIGHT OF THE LETTER OF EMPEROR ISAAC II TO POPE CELESTINE III
}

\author{
UDC 94(497.11:439)"11"
}

\section{Ivana Komatina}

The Institute of History, Belgrade, Serbia

\begin{abstract}
The relationship between Serbia and Hungary during the $12^{\text {th }}$ century can be characterized as allied and peaceful. However, at the end of the $12^{\text {th }}$ century, Hungary attacked the Serbian territory. The paper analyzes the letter sent by the emperor Isaac II to Pope Celestine III regarding the Hungarian attack on Serbia. We learn from it that the Byzantine Empire protected Serbia in such circumstances, with the claim that Serbia has been "under Romania from ancient times". Also, since the letter was not dated, by internal analysis of the text we can conclude that it was composed in 1193, so the Hungarian attack could be dated from the end of 1192 until the middle of 1193.
\end{abstract}

Key words: Serbia, Hungary, Isaac II, pope Celestine III, letter, Hungarian attack.

The struggle of the Serbs for independence from Byzantium, almost from the very beginnings, was inseparable from Hungarian-Byzantine warfare. It seems that such an attitude on the part of the Serbs was inevitable, since in the Balkans only the Kingdom of Hungary was capable of competing with the powerful Byzantine empire of the Comneni and Angeli.

The Serbs, "preparing the apostasy", used the Hungarian-Byzantine struggles from the time of King Stephen II and the Byzantine emperor John II Comnenus to destroy the fortress of Ras and start a rebellion against the imperial authority (Cinnamus 1836, 1012; VIINJ 1971, 14-17; Kalić 2006a, 380-381). The reason for the commencement of the war in 1127, according to the Byzantine writers John Cinnamus and Nicetas Choniates, was that the Byzantine court had given asylum to Almos, an uncle and a pretender to the throne of the current Hungarian King Stephen. Commander of the fortress of Ras, Critoples, was soon punished by the emperor, but the Serbs, despite this, did not have

Received June 12, 2018 / Accepted October 18, 2018

Corresponding author: Ivana Komatina

The Institute of History, Kneza Mihaila 36/II, 11000 Belgrade, Serbia

E-mail: ivana.komatina@iib.ac.rs 
significant successes, because the main clashes of the war were along the Danube and Great Morava, between the Byzantines and Hungarians. However, they also did not last long, but soon, in 1129, they ended in peace. The border remained unchanged, Byzantium retained Belgrade and Braničevo, and the Hungarians rebuilt Zemun (Cinnamus 1836, 12-13; Kalić 2006a, 380-381). After that, the Serbs suspended any independent actions against the Empire, and the new opportunity came about at the time of an event of transcontinental proportions, the Second Crusade (Komatina 2016a, 66-73). Cinnamus states that "the Alamans, Dalmatae and Peones" then entered into an alliance against the Empire, since they heard that "it was preparing for the war in Sicily" (Cinnamus 1836, 101-102; VIINJ, 1971, 22-23). Two expeditions of the emperor Manuel against the Serbs followed. In the first, which took place in 1149, he burnt down the "royal court of the arch-župan" Uroš II, while during his second campaign in 1150, Hungary sent to the Serbs military assistance (Cinnamus 1836, 103; VIINJ, 1971, 26-38). Although the Serbs were defeated in the great battle on the Tara River, there remains testimony of the joint action of the Serbs and the Hungarians against the Empire. Moreover, after the victory over the Serbs in 1151, emperor Manuel I Comnenus "went to the Huns' land", and the reason for the war was precisely the fact that the Hungarians provided "allied aid to the Dalmatians" (Cinnamus 1836, 113; VIINJ, 1971, 39). The Hungarian-Byzantine fighting ended in 1155 again without major changes at the border (Cinnamus 1836, 119-130; VIINJ, 1971, 45-55). In the 1160s, the struggle for the throne in Hungary between relatives started, in which Byzantium took part. The reason for the Hungarian-Byzantine warfare was the so-called "Patrimony of Bela". Namely, Stephen III handed over his younger brother Bela and his patrimony: Croatia, Dalmatia and Syrmium to the emperor Manuel, but as he did not abide to the original agreement, the Hungarian-Byzantine warfare began. After heavy fighting between 1162 and 1167, Byzantium included the said regions within its borders, and the northern border of the empire remained on the Danube. Also, within the framework of the Byzantine-Hungarian war, the grand župans of Serbia, set up by the emperor at his will, were again disobedient to the Byzantine authority, and were punished, among other things, for cooperation and negotiations with the Hungarian court (Cinnamus 1836, 212-270, VIINJ 1971, 55-101; Komatina 2016b, 157).

However, in 1166, Stephen Nemanja was on the Serbian throne, and unlike his predecessors, without the consent of the emperor (Pirivatrić 1991, 130-131; Pirivatrić 2015, 158-166). The Byzantine protegee, Bela III, came to the Hungarian throne in 1172 with the emperor's consent (Cinnamus 1836, 287; VIINJ, 1971, 102; ISN, 210). Nevertheless, after the death of emperor Manuel in 1180, they started a joint struggle against Byzantium. Bela III succeeded in returning Croatia, Dalmatia and Syrmium in the next year, but also directed his military campaigns towards the Danube and Morava (Moravcsik 1933, 558-562; Bubalo 2016, 64). Nemanja joined the fighting in Pomoravlje, but he also furthered his action in the Maritime region (Stefan Prvovenčani 1999, 36, 28, 40; Komatina 2018c). The war between the Hungarians and Byzantium was suspended in 1185, when Belgrade and Braničevo were returned to Byzantine hands as a dowry because of the marriage between Isaac II Angelus and Margarete, the daughter of King Bela III (Choniates 1975, 368; Stephenson 2000, 289). Stephen Nemanja also had to return a significant territory in the southwest of Serbia to Byzantium after the defeat in the battle of Morava in 1191 (Pirivatric 2015b, 50-51). The peace that was made after the battle was confirmed by the marriage between his son Stephen and Eudocia, the niece of the current emperor Isaac II Angelus (Ferjančić 1964, 217-224; VIINJ 1971, 246; Komatina 2016b, 180-181). Despite the fact 
that the son of the Serbian grand župan married a relative of the emperor, Serbia failed to enter the list of independent states after this great defeat, but in some way renewed its subordination to the Byzantine empire, certainly in a different form than it was in the early and mid-1 $12^{\text {th }}$ century (Komatina 2018c).

So, almost for a century, Serbia and Hungary fought against the Empire in order to suppress the influence of Byzantium in the Balkans. The war was, as we have seen, with more or less success, but it is undisputed that Byzantium did not easily leave strategically important areas along the Morava, the well-known Via Militaris. Hungary regained certain territories, but Belgrade and Braničevo remained Byzantine. After almost half a century of fighting for independence from Byzantium, Serbia had again to seek the path to winning independence and resisting the political influence of the Byzantine Empire.

It is in the light of these recent developments between Serbia, Byzantium and Hungary that it is necessary to analyze a letter sent by Isaac II to Pope Celestine III regarding the Hungarian attack on Serbia (Tornikès 1970, 337-345). The letter tells us that after decades of intense alliance and cooperation, Hungary attacked Serbia because it "wished power over it" (Tornikès 1970, 343). But before we try to give a more detailed historical analysis of the lines of the letter that talk about this attack, it is necessary to write a few words about its author and the time of composition. The letter was compiled for the emperor Isaac II by Demetrius Tornikès, a Byzantine nobleman who performed a very important function in the Empire, the logothetes of the dromos - he was responsible for the imperial post, the diplomatic and intelligence service, that is, the position that could only be performed by an emperor's "most trusted man". As the envoys of emperor Isaac II Angelus arrived in Rome before October 1, 1193 (Dölger 1977, No. 1615), Vitalien Laurent rightly takes that date as the terminus post quem non for the composition of the letter. Namely, the letter alludes to the wars between the Germans and Normans, which were led from 1191-1194, and in December 1194 South Italy was captured, with which the agonizing struggles ended (Laurent 1940, 27-29; Laurent 1941, 124-130). The earliest events described in the letter, in Laurent's opinion, could have occurred after 1191 , or, as he points out, "the allusion to a general conflict presupposes the return to France of Philip II August from the Crusade in Syria at the end of 1191, as well as the intensification of his intrigues against Richard the Lion Heart, who remained in Palestine during 1192/1193" (Laurent 1940, 29).

Thus, the letter describes the events that occurred between the end of 1192 and 1193, and was written before October 1, 1193 (Tornikès 1970, 336, n.1), when the Byzantine mission arrived in Rome. In the comments that accompany the translation of one part of the letter in the Byzantine sources for the history of the peoples of Yugoslavia, B. Ferjančić agrees that the letter "was probably sent in the first years of the pontificate of Celestine III (winter 1192/1193)" (VIINJ 1971, 249), but for some reason, the years 1191-1192 stand in the header of the work, as the years when the Hungarian intervention took place (VIINJ 1971, 250). There is no doubt that the Hungarian intervention occurred in 1192 or before the mid-1193 (Radojčič 1954, 18; Bubalo 2016, 73; Madgearu 2017, 102). If we take into account the fact that there are fairly certain indications that the Battle of the Morava between the Serbs and the Byzantines was fought after the autumnal equinox in 1191, after which peace negotiations followed, then the Hungarian attack that provoked Byzantium to stand forth as a protector of Serbia certainly happened after the situation between the initial opponents was pacified (Pirivatrić 2015b, 50-51). Moreover, Laurent also points out that Hungary could take advantage of the occupation of emperor 
Isaac II in the East, in the war against the Seljuk Turks, during the winter of 1192/1193 (Laurent 1941, 125). Also, Tornikès refers to the attack at the very end of the letter (Tornikès 1970, 343, 345), so taking into account all of the previously said, the Hungarian attack on Serbia should be placed at the end of 1192 or by the mid-1193.

Now, when it is clear in what time frame the Hungarian intervention or attack on Serbia occurred, attention should be paid to the very interesting lines that Isaac II exposes about this. The letter unfolds events concerning the overall conflicts within the Christian world and then, at the very end of it, Isaac II relates to Pope Celestine III the troubles that befell Byzantium at the hands of Hungary. Namely, the emperor points out how the waves of dissatisfaction caused by these events stretched over Europe and reached the Danube region, which is why, "the, until recently, generous father-in-law of My Imperial person ... dissatisfied with his own inheritance, which he hardly got with the military and financial assistance of Romania, wished the power over Serbia" (Tornikès 1970, 343).

Thus, after almost a century of allied relations in the $12^{\text {th }}$ century during which the Serbs always cooperated with the Hungarians, after decades of fostering military and diplomatic alliances, the latter "wished power over Serbia“" (Klaić 2006b, 153-172; Kalić 2006c, 623-642). So, from the letter we learn that Hungary wanted to extend its power over Serbia, all because of its "dissatisfaction with inheritance". Namely, the emperor alludes to the fact that Bela III ascended the throne in 1172 with the help of Byzantium (ISN 1981, 210). He also points out that Hungary cannot claim rights over Serbia because it has been "from ancient times under Romania", and that Bela ignored the oath he gave to emperor Manuel. At this point he meant the oath by which Bela undertook the obligation to be a friend of the Empire "for all time" and would never fight the Empire after he "sent him to receive the inherited power" in 1172 (Tornikès 1970, 343; Cinnamus 1836, 287; VIINJ 1971, 102). Then Isaac states that Bela thereby violated another oath, "the one he gave to the Empire again when he concluded a treaty with the My Imperial person, and my beloved Augusta, his daughter", when it was also agreed that he would not do anything against the "rights of Romania", "nor against Serbia". It is assumed that there the emperor Isaac II refers to the contract between the Byzantines and Hungarians which was concluded at the occasion of the marriage between him and Bela's daughter Margaret in 1185 (Choniates 1975, 368; Stephenson 2000, 289). However, if we read it carefully, we see that Bela then committed to not doing anything against Serbia. It is known that Serbia was an ally of the Hungarians in the war against Byzantium, which began in 1181, so we consider that the Byzantine-Hungarian peace from 1185 would not in any case concern Serbia in such circumstances, that is, the obligation of not attacking Serbia would be unnecessary. In all likelihood this oath was rather related to the period after the Battle of Morava in 1191. Namely, after the victory in the battle of Morava the emperor Isaac II, as sources testify, went to Belgrade to meet his father-in-law Bela III (Stephenson 2000, 301). It is possible that it was then that the "conclusion of a treaty" between the Empire and the Kingdom of Hungary came about. Then, as said, Bela III was obliged not to raise arms against Byzantium, or Serbia (Tornikès 1970, 343), which after its defeat lost the independence for which Stephen Nemanja in particular, but also his predecessors, fought with undeniable dedication. Byzantium could then regain its "authority from ancient times" over Serbia (Tornikès 1970, 343), because of which it concluded a treaty of nonaggression with Hungary. However, as we have seen, the emperor appealed to the Pope precisely because of the violation of the same, and in the following lines he writes: "He (the King of Hungary, I. K.) rose up in arms against it (Serbia) without the consent of the 
My Imperial person, set an army against it, believing that he would win it in the first run" (Tornikès 1970, 343). It is assumed that the Hungarian attack probably took place in the area of northwestern Serbia (Madgearu 2017, 102). Furthermore, in the letter the emperor quotes that he immediately sent a military detachment to the "grand župan of Serbia", Stephen Nemanja, and thus urged the Hungarian army to withdraw, but that they refused to "return to the one who sent them" (Tornikes 1970, 343). In the end, the emperor wrote to the pope that he "preserves Christianity", and that he therefore turned to the King of Hungary "through mild letters", trying to "soften him (the Hungarian king) and save from the great arrogance" (Radojčić 1954, 18; Tornikès, 1970, 343, 345). The emperor ends the letter in a rhetorical-religious style, not bringing further news of the Hungarian campaign (Tornikès 1970, 345).

Thus, the Hungarian attack on Serbia took place at the end of 1192 or by mid-1193. The place of attack is not known, but it was most probably in the northern parts of the then Serbia. The emperor sent a detachment that was supposed to help the Serbian grand župan Nemanja. After that, the Hungarian army retreated, but in all likelihood provoking additional struggles. The Byzantine emperor tried to calm the king of Hungary in a diplomatic manner and win him over to stop the action. Unfortunately, the letter does not disclose the epilogue of this Hungarian attack, either on Serbia or Byzantium. However, it is well known that the emperor Isaac II and the Hungarian king Bela III fought together against the Bulgarians in 1195 (VIINJ 1971, 252, p.19; Stephenson 2000, 303-304), but also that Stephen Nemanja handed over the preserved state to his son Stephen Nemanjić in 1196, which indicates that the attack had no greater consequences, either in the relations between Byzantium and Hungary, or for Serbia.

Serbian-Hungarian relations became far more complicated during the $13^{\text {th }}$ century. Hungarian king Emeric added to his already complex intitulation the title Rex Serviae, so he styled himself as: "Hemericus, Dei gratia, Hungariae, Dalmatiae, Croatiae, Ramae Serviaeque rex in perpetuum" (Komatina 2017, 88). After that, the conflicts between the two states became more frequent, and the Hungarians often used to justify them with their right over Serbia.

Acknowledgement: Prepared as a part of the project Medieval Serbian Lands (13-15th Centuries): Political, Economic, Social and Legal Processes (177029), supported by The Ministry of Education and Science and Technological development of the Republic of Serbia.

\section{REFERENCES}

Bubalo, Đorđe. Srpska zemlja i pomorska u doba vladavine Nemanjića, I. Beograd: Filip Višnjić, 2016.

Ćirković, Sima, ur. Istorija srpskog naroda, I. Beogard: Srpska književna zadruga, 1981.

Dölger, Franc and P. Wirth, eds. Regesten Der Kaiserurkunden Des Oströmischen Reiches von 565-1453. 2nd ed. Munich: C. H. Beck, 1977.

Ferjančić, Božidar. "Kada se Evdokija udala Stefana Nemanjića?“" ZFF 8/1 (1964): 217-224.

Darrouzès, Jean, éd. Georges et Dèmètrios Tornikès, Lettres et discours, Paris 1970 (= Tornikès 1970).

Juhas-Georgievska Ljiljana i Tomislav Jovanović. Stefan Prvovenčani, Sabrani spisi. Beograd: Srpska književna zadruga, 1999.

Kalić, Jovanka. "Niš u srednjem veku“. U Evropa i Srbi. Srednji vek, uredio T. Živković, 369-409. Beograd: Istorijski institut, 2006a.

Kalić, Jovanka. "Župan Beloš“. U Evropa i Srbi. Srednji vek, ur. T. Živković, 623-643. Beograd: Istorijski institut, 2006b. 
Kalić, Jovanka. "Raški veliki župan Uroš II“. U Evropa i Srbi. Srednji vek, ur. T. Živković, 153-173. Beograd: Istorijski institut, 2006c.

Komatina, Ivana. "Srbi na putu krstaša." IČ 65 (2016a): 66-73.

Komatina, Ivana. Crkva i država u srpskim zemljama od XI do XIII veka. Beograd: Istorijski institut 2016b.

Komatina, Ivana. "Rex Serviae u ugarskoj kraljevskoj tituli od 1202. do 1402“". Niš i Vizantija XVI (2017): 87-102.

Komatina, Ivana. I obnovi svoju dedovinu i bolje je utvrdi je utvrdi - Stefan Nemanja i Stefan Prvovenčani i uobličavanje srpske državnosti [Komatina 2018, rad u pripremi za štampu].

Laurent, Vitalien. "La Serbie entre Byzance et la Hongrie". Revue Historique du sud-est Européen 18 (1941): 109-130.

Laurent, Vitalien. "Rome et Byzance sous le pontificat de Célestine III (1191-1198)“. Échos d' Orient 39 (1940): 26-58.

Madgearu, Alexandar. The Asanids: The political and military history of the Second Bulgarian Empire (11851280). Leiden: Brill, 2017.

Meineke, August, ed. Ioannis Cinnami Epitome rerum ab Ioanne et Alexio Comnenis gestarum. Bonnae: Weberi, 1836

Moravcsik, Gyula. "Pour une alliance Byzantino-Hongroise (seconde moitié du XII siècle)“. Byzantion 8/2 (1933): 555-568.

Van Dieten, Jean-Louis, ed. Nicetae Choniatae Historia. Berolini-Novi Eboraci: De Gruyter, 1975

Ostrogorski, Georgije i Franjo, Barišić, ur. Vizantijski izvori za istoriju naroda Jugoslavije, IV. Beograd: Vizantološki institut SANU, 1971.

Pirivatrić, Srđan. "Byzantine-Hungarian Relations in 1162-1167 and the Desposition of Serbian Grand Župan Desa“. Byzans und das Abendland III. Studia Byzantino-Occidentalia, 158-166. Budapest: Eötvös-JószefCoolegium 2015a.

Pirivatrić, Srđan. „Hronologija i istorijski kontekst podizanja manastira Studenice. Prilog istraživanju problema“. Zograf 39 (2015b).

Pirivatrić, Srđan. „Prilog hronologiji Nemanjine vlasti““. ZRVI 29-30 (1991).

Radojčić, Nikola. "Promena u srpsko-madžarskim odnosima krajem XII veka“. Glas SKA (1954): 1-21.

Stephenson, Paul. Byzantium's Balkan Frontier: A Political Study of the Northern Balkans. Cambridge, 2000.

\section{O POHODU UGARSKOG KRALJA BELE III NA SRBIJU U SVETLOSTI PISMA CARA ISAKA II PAPI CELESTINU III}

Odnos Srbije i Ugarske tokom XII veka može se okarakteristai kao saveznički i miroljubiv. Međutim, krajem XII veka došlo je do napada Ugarske na srpsku teritoriju. U radu se analizira pismo koje je car Isak II uputio papi Celestinu III, a tiče se ugarskog napada na Srbiju. Iz njega saznajemo da vizantijski car štiti Srbiju usled takvih okolnosti, uz tvrdnju da je Srbija „od davnina pod Romanijom “. Takođe, budući da pismo nije datirano, unutrašnjom analizom teksta da se zaključiti da je nastalo 1193, odnosno ugarski napad se može smestiti u period od kraja 1192. do sredine 1193.

Ključne reči: Srbija, Ugarska, Isak II, papa Celestin III, pismo, ugarski napad. 